\title{
Study on the Challenges for Teachers of English teaching Reform
}

\author{
Wuying $\operatorname{Tan}^{1}$ \\ ${ }^{1}$ Nanchang Institute of Science \& Technology, Nan Chang, Jiang Xi, 330108 \\ 346591653@163.com
}

KEYWORDS: Challenges; English Teaching; Teaching Reform

\begin{abstract}
With the process of reform of national college English teaching, college English teachers face "three to improve" the pressure and the corresponding challenges. This paper believes that the teacher is the main dominant teaching is teaching. They brought pressure and challenges of reform and to deal with the attitude is very important. As countermeasures, the most fundamental is that teacher self-development and self-development, including learning, research, restructuring, reform and innovation practices. This article was in keeping college English teaching reform process context, on the pressures and challenges facing teachers, attitudes towards reform and ways to cope explore the theory and practice of conduct.
\end{abstract}

\section{Introduction}

"College English Curriculum Requirements (Trial)", as the main basis for the university college English teaching reform organizations. "Course requirements" proposed "college English teaching goal is to develop students' English language proficiency, especially listening and speaking, so that they can use English in future work and social interaction effective oral and written information exchange, while enhancing its self-learning capability, enhance cultural awareness, in order to meet the needs of social development and international exchanges. On this basis, proposed "Based Multimedia computer and classroom teaching mode", launched a college English teaching reform national scale. Facing the new situation and new standards, the challenges of college English teachers receive is comprehensive. Teacher's role and the concept of being challenged, in turn will affect teaching practices of teachers, therefore, teaching methods teachers also been challenged. At the same time, students expect teachers has changed, how to guide students to adapt to the new teaching model, is also a major challenge teachers had to face.

\section{The Challenges for Teachers of English teaching Reform}

Teaching requirements in 2004 the Ministry of Education promulgated the "College English Curriculum Requirement (on Trial)" is the goal and direction of the Programme of college English courses. The file in teaching objectives, contents, methods, models, tools, evaluation and horizontal positioning have made great reforms. For example, to improve the ability of English listening and speaking communication requirements, proposed the implementation of computer and network-based teaching model, emphasizing the Students' comprehensive English ability. The English teaching is a complex project, which requires impact studies teacher learner individuals, groups and society of various factors on English teaching and learning, teachers are required to deal with restricting the role of the English language teaching and learning environment and teaching environment, requirements teacher selection, design teaching purposes, teaching and teaching 
methods, teaching model also requires teachers to build and create, the choice of teaching methods and techniques. Thus the pressure facing teachers is to be learning and development needs of classroom teaching interpersonal communication skills and communication activities of the organization management, computer skills and network monitoring capabilities based on self-learning requires teachers to computers and networks.

With the reform of the guiding role of the student level primary and secondary English curriculum standards, implementation and reform NMET played, starting Freshmen of English proficiency has improved to varying degrees. In addition, the media in English and social English tutoring school students also make contact with English-speaking environment and conditions getting better, they are college English teaching methods of the demands and expectations have begun to change. Traditional lecture-type and unity of college English teaching mode and method clearly out of date. Accustomed to the long-established formula of teachers to teach legal challenges encountered in transition role and methods of innovation.

Assessment criteria for teachers with modern trends in foreign language education reform concepts and methodology, as well as university personnel system in advance. School teachers assessment criteria are changing. In addition to teaching workload assessment content, also involves teaching methods and means, quizzes and papers of standardization, teaching evaluation results, teachers to students online self-learning monitoring the status of implementation, teaching and research findings. Such comprehensive evaluation of teaching performance to income, job title, job hooks, forcing teachers new ideas, improve teaching, so that the quality and quantity, student satisfaction, the effect is significant. These will undoubtedly challenge the ability of English teachers in teaching, design, technology and the like. In addition, the information age continue to generate new ideas, new achievements, teaching material written in constantly changing teaching content to be expanded, which requires teachers to play the body constantly absorbing and transforming consciousness. Teachers are the main dominant teaching is teaching. Only by promoting the continuous development of English teachers themselves, in order to face tough challenges, adapt to English teaching reform

\section{Cope with Stress and Challenges}

Copewith stress and challenges, the first is attitude. There are two different attitudes: one is conflict resist; the other is a positive challenge.

Negative attitudes toward college English teaching reform will form resistance. For example: the concept of resistance, the role of language function, teachers and students, teaching the principles of traditional understanding does not update; Awareness Resistance: the lack of reform, challenge, sense of urgency; the attitude of resistance: attitude boycott / conflict, or no psychological adjustment, or complaining; customary resistance: mindset and stereotypes lead role is difficult to change behavior and methods, including self-change and assist teachers to guide students to change two links; capacity resistance: does not have the ability to operate the new method of teaching, I do not know how to develop new Teaching ability required and the like; action resistance: investment is not enough, the negative practice, difficulties discouraged frustrated not insist. Positive attitude has action. Teachers To tide of reform ownership attitude in consciousness, ideas, attitudes, habits, the ability to transition, poverty, innovation and development; the need to study hard, good teaching, good research, innovation. Through teaching and learning, teaching and research phase benefits, the creation of the update to reach self-development. Specific actions include: learning first. Teachers do not learn to depletion of resources, the development will stagnate. Learning on the one hand by regular quantitative reading books and papers of foreign language education; on the other hand to 
make full use of various resources, including students, teaching materials, classroom, colleagues, experts and resources from the community. The most effective learning is in practice school, learning by doing, to ensure that the investment in science, stress methodology, the pursuit of the effect of school.

Practice is important. College English teachers objects both numerous and complex, a lot of practice platform space. Therefore, there must be awareness purposefully carry out teaching practice, creative practice, the reform of the practice, theory and practice, cooperative practice, summarized lifting theory, innovation in practice, reform and development from practice. Practice student-centered, competency goals to communication for the purpose of the method as a guide to the process as the key to quality education and humanities general education curriculum content. In terms of methods, tools, patterns, materials, lesson plans, courseware, activities, tasks, etc. from the micro reform and innovation. For example, try the task-based practice, collaborative, interactive, communicative, authenticity, situational method, functional approach, themes law, the role of law, seminars, case law, media, social and other teaching methods, focusing on practice, and stress practical effect. Study should keep up. Although college English teachers is defined as "teaching oriented" university teacher groups, but teaching and research is still essential part of career. Do teachers should do and can do research. For example: in conjunction with their practice of teachers and teaching methods, students and law school, classroom, curriculum, mode, textbooks, relationships, behavior, roles change, misunderstanding, discrimination, dislocation, "ditch", authenticity, test and evaluation and teaching-related people and things. Research methods are to quantify, qualitative, action, case law, narrative, observation. Any study must be under the foot work, including reading, writing, communication, experiments, investigations, studies all aspects.

The most critical requirement for teacher reform and innovation is the "transition." Teachers from the traditional role into modern role, it must distinguish the nature of traditional and modern teaching are relatively clear and comprehensive understanding. The essential difference between traditional teaching and modern teaching is reflected in the teacher's behavior, the key is to reassign teachers and students to achieve power. Empowerment of teachers to students, provide opportunities for them to learn the full exercise of dominant factors and regulatory powers of learning behavior, really responsible for their own learning. Including the disbursement of student control over the learning resources, learning time and learning effort, learning measurement and the like; the regulation of force including the regulation of student learning attitude, learning methods and learning pathways and learning goals. These powers have been concentrated in the hands of teachers. From the "teacher-centered" to "student-centered" is a substantial "transfer of power." Let the right of teachers to students in the teaching process, decentralization and empowerment, education today advocated "people-oriented" and "student-centered" is all about. Classroom teachers and students a new way to get along with each other, that is dominion and control over the use of a unilateral right to change the teachers for students in which the individual and his co-domination and control groups. This includes a participatory, democratic, cooperative, interactive and complementary process, both inside and outside the classroom naturally formed a team, in an effort to achieve a common goal or shared. In accordance with the standards of modern education, the school is important is to develop the ability to learn, rather than access to learning content. The ability to acquire and develop other people can not do it in. Teacher out of the old, familiar, easy kind of "monopoly", "indoctrination type", "to explain the style", "do the job" of teaching mode, students to independent learning, cooperative learning, communicative learning opportunities, space, and the effective date of the conditions is that when foreign language teaching reform success. 


\section{Conclusion}

Complementary process, naturally formed a team outside of the classroom in an effort to achieve a common goal or shared. In accordance with the standards of modern education, the school is important is to develop the ability to learn, rather than access to learning content. The ability to acquire and develop other people can not do it in. Teacher out of the old, familiar, easy kind of "monopoly", "indoctrination type", "to explain the style", "do the job" of teaching mode, students to independent learning, cooperative learning, communicative learning opportunities, space, and the effective date of the conditions is that when foreign language teaching reform success.

\section{REFERENCE:}

[1] Xia Jimei. University English Teacher Education Concept, Knowledge, Ability, Scientific Research and Education Status Survey Report [J]. Western World, 2002, (5): 35-41.

[2] Wu Shixing. The Introduction of Multimedia Network Technology, Reform The Traditional Teaching Model [J]. Western World, 2003, (6).

[3] Department of Higher Education of College English Curriculum Requirements (Draft) [M]. Beijing: Foreign Language Teaching And Research Press, 2004.

[4] Su Dingfang. Foreign Language Teaching: Problems And Countermeasures [M]. Shanghai: Shanghai Foreign Language Education Press, 2004. 